Japanese Yearbook on Business History - 1999 / 16

\title{
Nationalization of Railways
}

The Japanese and British Cases

\author{
Takeshi YuZAwA \\ Gakushuin University
}

$\mathrm{W}$

HY DISCUSS NATIONALIZATION of railways in an age of privatization? As we look around us, we see that people around the world seem to think that the managerial and financial problems of public enterprises can be solved by privatization. Sometimes privatization is considered to be a magical solution to these problems. Still, it is good to go back to the time when nationalization was all the rage, when there were hot debates about the difficulties of private companies, especially the problems caused by their monopolistic power, so that gradually governments increased their power to intervene and control private companies and eventually nationalized them. From this point of view, understanding more about the process of nationalization would be quite important for understanding the meaning and limitations of the privatization currently being carried out in many countries.

Railways were, from their earliest days, under the strong control of their governments, even in the U.K. in the heyday of laissez-faire. Why were the railways under the strong control of governments? There are three main reasons for this.

The first is that a railway has to pass through large numbers of pri- 
vate properties over long distances; in order to make the railway run the shortest distance between two points and over profitable routes, the promoters have to trespass on private property to lay the rails. They are required to obtain a wayleave from the parliament to entitle them to build tracks through private land; without such a legal authorization, the railway company could be sued by landowners for trespassing on private property.

The second is that the government regulates railway fares and rates from the very beginning, since the railway is considered a common carrier. A railway, by nature, is monopolistic, especially after a railway company begins to use exclusively its own tracks. In the early stage of a railway, it functions very much like a canal, and its tracks are open to use by the public. But once a railway started to make full use of locomotive power, it became impractical to allow its tracks to be open to use by the public, and other railway companies were not readily able to construct lines on the same route because of strong opposition from the existing railway company. Because of the kind of expensive infrastructure that railway tracks represent, it is quite logical and reasonable for governments to intervene in order to avoid having rival companies all building their own tracks. During the first stage of railway history, governments regulated not only the fares and rates of the railway companies but also their dividends and borrowing powers. For instance, the Liverpool and Manchester Railway (opened in 1830) had its dividend regulated to no more than 10 percent and its borrowing power limited to one-third of the total ordinary paid capital. This shows that Parliament considered a railway to be a monopoly, and so it intervened in the private company's plans and pricing policies. ${ }^{1}$

The third reason is that railway companies are obliged to look out for the safety of train passengers, the people crossing the rail tracks, and the workers in their companies. The government is therefore required to provide various rules to secure the safety of the passengers and workers and to prevent accidents caused by the railways. The first fatal accident that occurred in England was on the first day of the Liverpool

I Robert E. Carlson, The Lizerpool and Manchester Railakcy 1821-1831 (1969), pp. 109, 159. 
and Manchester Railway in 1830: Mr. William Huskisson, MP for Liverpool, was killed by the train demonstrating the new track. ${ }^{2}$

As early as 1844 the British Parliament discussed nationalization of the railways and passed the Gladstone Act of railway nationalization with its article on the parliamentary train, which ran for the poor at a rate of one pence per mile. Although nationalization of the railways did not come about in the nineteenth century, heated discussions on the possibility of nationalization took place. Nationalization of the railways was seriously debated at the end of the nineteenth and the beginning of the twentieth centuries. ${ }^{3}$

In the case of Japan, which began its industrial revolution more than a hundred years after England, the government had to take a leading role in transferring Western technological advances, among which the railway was one of the most important. As Alexander Gerschenkron explains, ${ }^{4}$ backward industrial countries had to rely upon governmental power to organize and promote modern industries. For Japan to catch up with Western countries, the Meiji government started to introduce not only the railway but also other key industries such as shipbuilding, mining, iron and steel, and others.

At first the Meiji government tried to construct railways by itself, but within ten years of its first railway (completed in 1872) it had to abandon its plan of constructing only a governmental railway, because of its lack of money and the vigorous demands of capitalists wanting to construct railways themselves. There was, for a while, coexistence of the national and private railways in Japanese trunk lines, but the private railways were under the strong control of the government. But there were always strong arguments being made for nationalization of the main lines, especially with reference to the mobilization of forces and goods in a time of war. In the course of this paper we shall examine some of the characteristics of railway/government relations in Japan.

In The Times of 1 October 1912 we find some statistics on the ownership of the world's railways; there were 453,553 company-owned railways as opposed to 186,068 state-owned railways. The former came

2 Ibid., p. 234.

${ }^{3}$ Terry R. Gourvish, British Railunays 1948-73, pp. 13-14.

"A. Gerschenkron, "Social Attitudes, Entrepreneurship and Economic Development," Exploration in Entrepreneurial History 4, no. 1, 1953. 


\section{Table 1. Ownership of World Railways}

Area

Owned by

State

Companies

Percentage

Europe

107,663

99,632

51.9

48.1

America

12,190

314,693

3.7

96.3

Asia

36,710

26,581

58.0

42.0

Africa

13,668

9,222

59.7

40.3

Australasia

18,027

1,285

93.6

6.4

World total

188,258

451,363

29.4

70.6

Source: The Times, 1 October 1912.

to $70.9 \%$ of the total; the latter, to $29.1 \%$. Thus, prior to World War I railways around the world were predominantly private.

But note that there are big unbalances in each area, especially in the continent of America, where railways were dominantly privately owned, whereas in Australasia more than 90 per cent of the railways were state owned. Furthermore, U.S. railways made up $37.7 \%$ of the world's total, and if they are excluded, we find the ownership follows a similar pattern in the other areas, with state ownership slightly higher than private ownership in all areas. In other words, before World War I, most countries were considering which type of ownership of the railways was better.

In this paper we focus on the cases of Japan and Britain and discuss the major difference between two countries in regard to nationalization and the similarities between them. In Japan nationalization of the major railways took place in 1906; in England there were bitter arguments over the possibilities of state ownership, and in 1921 all the railways were consolidated into four railway companies. This was just a preliminary stage to nationalization. In one sense, the British railway consolidation was much more dynamic than Japan's nationalization, because many small and local railways, and urban electric railways, remained private companies in Japan. 


\section{Table 2. A Comparison of Third-Class Passenger Fares}

\begin{tabular}{lrrrrrr} 
& \multicolumn{2}{c}{12 miles } & \multicolumn{2}{c}{184 miles } & \multicolumn{2}{c}{402 miles } \\
& \multicolumn{1}{c}{ single } & return & single & return & single & return \\
U.K. & $1 \mathrm{~s} .0 \mathrm{~d}$. & $1 \mathrm{~s} .8 \mathrm{~d}$. & $15 \mathrm{~s} .51 / 2 \mathrm{~d}$. & $30 \mathrm{~s} .11 \mathrm{~d}$. & $33 \mathrm{~s} .0 \mathrm{~d}$. & $62 \mathrm{~s} .11 \mathrm{~d}$. \\
Belgium & $0 \mathrm{~s} .71 / 2 \mathrm{~d}$. & $0 \mathrm{~s} .11 \frac{1}{2} \mathrm{~d}$. & $9 \mathrm{~s} .0 \mathrm{~d}$. & $14 \mathrm{~s} .2 \mathrm{~d}$. & $19 \mathrm{~s} .6 \mathrm{~d}$. & $31 \mathrm{~s} .4 \mathrm{~d}$. \\
Switzerland & $0 \mathrm{~s} .93 / 4 \mathrm{~d}$. & $1 \mathrm{~s} .0 \mathrm{~d}$. & $12 \mathrm{~s} .2 \mathrm{~d}$. & $15 \mathrm{~s} .3 \mathrm{~d}$. & $26 \mathrm{~s} .8 \mathrm{~d}$. & $33 \mathrm{~s} .5 \mathrm{~d}$. \\
Germany & $0 \mathrm{~s} .7 \mathrm{~d}$. & $1 \mathrm{~s} .2 \mathrm{~d}$. & $10 \mathrm{~s} .0 \mathrm{~d}$. & $20 \mathrm{~s} .0 \mathrm{~d}$. & $22 \mathrm{~s} .3 \mathrm{~d}$. & $44 \mathrm{~s} .5 \mathrm{~d}$. \\
Denmark & $0 \mathrm{~s} .61 / 2 \mathrm{~d}$. & $1 \mathrm{~s} .11 / 2 \mathrm{~d}$. & $7 \mathrm{~s} .2 \mathrm{~d}$. & $14 \mathrm{~s} .4 \mathrm{~d}$. & $11 \mathrm{~s} .8 \mathrm{~d}$. & $23 \mathrm{~s} .4 \mathrm{~d}$.
\end{tabular}

Source: Emil Davies, The Case for Railway Nationalization, 1913, p. 51.

\section{BRITISH RAILWAYS ON THEIR WAYTO NATIONALIZATION}

THE RISE OF RAILWAY NATIONALIZATION IN THE U.K.

At the end of the nineteenth century, nationalization became a hot topic in the U.K. The reason for this was that, at a time of depression, many traders were decrying the high fares and rates of the railways. When traders complained about the high railway rates, Sir Charles Mark Plamer observed in Parliament that "I think the rates charged are in many cases so high that they are prejudicial to our productive industries, and more especially as regards agriculture." Furthermore, there was an international comparison of U.K.'s railway fares. Table 2 shows third-class fares charged for typical journeys on the railways of the United Kingdom, comparing them with some of the stateowned lines of the continent. The U.K. fares were two to three times higher than those of continental countries.

In March 1906, at the Conference of the Associated Chambers of Commerce, a member alleged that in England it cost 9s.10d. to carry a ton of goods 100 miles, while the cost to carry the same goods in all the principal countries of the world with which Britain competed for trade was $4 \mathrm{~s} .6 \mathrm{~d}$, and the average cost of carrying a passenger 100 miles in England was 8s.3d., while the corresponding charge in other parts of the world was $4 \mathrm{~s} .1 \mathrm{~d}$. English people paid $£ 60,000,000$ a year

\footnotetext{
${ }^{5}$ Final Report of Commission on Trade Depression, 1886.
} 
more than people in other countries for the same railway service. ${ }^{6}$ If these figures were correct, the fares on U.K. railways were roughly twice higher than those of other industrial countries, especially those of the state-owned railways on the continent.

The Railway News reported a Daily News article that said of the Dutch and German railways, both of which were state-owned, that "they have grown because the railways which feed them belong to the State, and obey a rational policy which makes the railway the servant and not the master of industry." Trade unions also bemoaned the high fares and rates and asked for nationalization of the railways against the background of the increasing powers of Fabianism.

The movement for railway nationalization gathered power and several organizations were launched. One of these was the Railway Nationalization League, formed in 1895. In 1908 the Railway Nationalization Society was also organized, with special pressure from traders who were struggling through the latest economic depression.

Emil Davies summarized the reasons for supporting nationalization: if the 217 railway companies came under state control, reckless competition would be avoided, and salaries paid to directors and managers would also be drastically reduced. Employees duplicating one another's jobs would be reallocated to improve the services. Station and other facilities would be merged and used more efficiently, and rolling stocks, including locomotives, carriages, and wagons, would be run more efficiently. As far as private companies were concerned, they had to spend money for advertisements. At present, companies' creditability differed widely, depending on the financial conditions of each company, but if they came under state ownership, their creditability would become uniform and stable. ${ }^{8}$

OPPOSITION TO NATIONALIZATION OF THE RAILWAYS

The opposition to nationalization can be summarized in a book by E. A. Pratt. He listed many reasons why he opposed nationalization:

(5) The Railway News, 10 March 1906.

7 The Railuay Nerus, 25 May 1907.

${ }^{8}$ Emil Davies, The Case for Railuay Nationalisation (London: Collins' Clear-Type Press, 1913). 
a. that the example of other countries that have adopted state ownership is not necessarily one that the U.K. should follow;

b. that the financial success of state-owned railways abroad is the exception rather than the rule;

c. that nationalization was mainly desired by the Labour Party and railway workers in the interest of class or personal benefits;

d. that there is no guarantee that railway strikes will be minimized;

e. that state operation would give rise to many serious political problems;

f. that the hopes of effecting substantial economies in operation have little chance of being realized;

g. that even if the country's traders did get some reductions in their rates, they might lose various facilities, or might have to endure various disadvantages;

h. that people in general would in no way be better off in regard to transport facilities than they were at present, and would instead have to run the risks of a decrease in those facilities, a lowering of the current standard of railway efficiency, and an increase in taxation. ${ }^{9}$

His recommendations were simple: that the principle of railway nationalization not be adopted in the U.K.; that, instead, the railway companies be permitted and encouraged to make, where necessary, such alliances or arrangements among themselves; and that Parliament, traders, and the public in general, should show a more sympathetic attitude towards the railways. ${ }^{10}$

Theoretically, the arguments for nationalism were quite persuasive and reasonable, considering the current conditions of the British railways. The Railway News reported a calculation of the cost of nationalizing British railways as made by the government: ${ }^{11}$

" E. A. Pratt, The Case against Railway Nationalisation (London: Collins' Clear-Type Press, 1913), chapter 10.

${ }^{10}$ This point should be seen as too unrealistic, because there were plenty of complaints from traders and customers, and Sir George S. Gibb, former general manager of the North-Eastern Railway, frankly admitted at the Royal Economic Society in November 1908 that "the first [reason] I will name, though it may not be the most influential, is the existence of a certain amount of dissatisfaction with the present state of railway administration." The Railusay Nerus, 24 November 1908.

1 The Railway Neus, 27 March 1909. 
The net revenue of British railways in the year 1907 was .....£44,940,000

From which must be deducted the undermentioned charges on the Government railway stock to be issued in exchange for the specified existing prior stocks:-

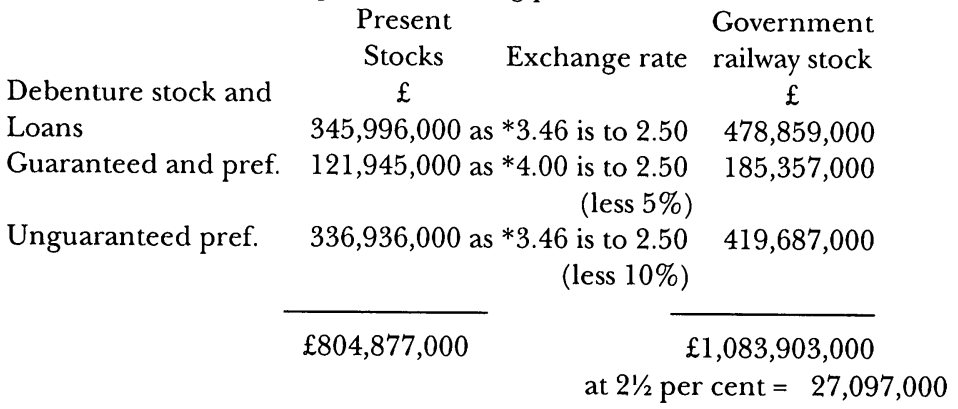

Leaving an annual free net revenue of $£ 17,843,000$

Which, at 30 years' purchase, would give the ordinary stockholders a capital sum (in Government railway stock) of. $£ 535,290,000$

The total cost to the Government would therefore be: -

In exchange for prior stocks $\ldots \ldots \ldots \ldots \ldots \ldots \ldots \ldots £ 1,083,903,000$

In exchange for dividend-earning ordinary stocks ......535,290,000

In exchange for non-dividend-earning stock—say .......30,000,000

Total $\ldots \ldots \ldots \ldots \ldots \ldots \ldots \ldots \ldots \ldots \ldots \ldots \ldots \ldots \ldots 1,649,193,000$

Which, at $2 \frac{1}{2}$ per cent. per annum, would absorb . . . . £41,230,000

And this sum deducted from the annual net revenue of 1907 of . . . . . . . . . . . 444,940,000

Leaves an annual surplus of $£ 3,710,000$

* Average rate of dividend or interest paid year 1907

From this calculation, the nationalized railway can produce an annual profit of $£ 3,710,000$. After World War I the Labour Party pressed for nationalization of railways and canals on the basis of a document entitled "Labour and the New Social Order" (1918). The Railway Nationalization Society produced a draft bill and proposed the purchase prices be based on a stock exchange valuation of the companies' securities, taken 6 to 18 months before the bill was introduced in parliament, with payment to be made in Government Railway Stock.

In the end, however, the 1921 Railway Act opted for continued private ownership, and it proved to be a halfway house to public own- 
ership. More than a hundred businesses were compulsorily merged into four large territorial groups, subject to heavy state regulation. The monopolistic potential of the new companies was feared, and their pricing policies and wage-fixing policies were constrained, and a limitation was put on their profit by a standard revenue norm. The new companies had to cope with the problem of integrating many constituent companies into single organizations, as well as with the severe competition of road transportation.

Economies of amalgamation were realized slowly, and net revenue increased modestly (by around 4 percent between 1923 and 1929). Gross receipts fell by some 13 million pounds, but costs declined more rapidly, by about 14.5 million pounds. The heaviest losses were in passenger traffic, where receipts dipped 13 per cent. This was a measure of increased competition from buses and private cars. Freight business was less affected at that stage, but revenue in that area inevitably reflected the poor performance of the railways' major customers: staple export industries. Thus the four railway groups made slow progress towards the target of standard revenue (eventually fixed at just over 51 million pounds, a return of 45 per cent on nominal capital) but failed to share fully in the economic growth of the $1920 \mathrm{~s}^{12}$

\section{JAPANESE RAILWAYS ON THEIR WAYTO NATIONALIZATION}

THE DEVELOPMENT OF THE JAPANESE RAILWAYS

Japanese railways started under the strong influence of Great Britain. There were 104 foreign engineers and laborers working on Japanese railways in 1876, when the number of foreigners was at one of its peaks. Of these, 94 were from Britain, two each were from America, Germany, and Denmark, and one each came from France, Italy, Finland, and Portugal. This gives a clear indication of the extent of British influence. The hired foreigners ranged from people in high-ranking positions, such as directors, engineers-in-chief, and locomotive superintendents, to such lower ranks as engine drivers, masons, carpenters, blacksmiths, tracklayers, and so on. Edmund Morell, a member of the

12 Gerald Crompton, "Good business for the nation: The railway nationalization issue, 1921-1947," The Journal of Transport Fistory, $3^{\text {rd }}$ ser., vol. 20, no. 2, September 1999, pp. $141-42$. 
Civil Engineers' Society in England, was first invited by the Japanese government as a chief engineer, and he was accompanied by John Diack, John England, and Charles Shepherd. ${ }^{13}$

At the end of the nineteenth century, a third of the total expenditure of Japanese railways went abroad for the purchase of materials, hence the matter was one well worth looking after. "Great Britain has practically had a monopoly in furnishing rails, engines, rolling stock, \&cc.; whether her manufacturers are still to enjoy this privilege must depend on themselves and on the exertions they make. The railways of Japan have been built under foreign, it might almost be said British, advisers. Hence it was convenient that the materials required for carrying out designs made by English engineers should be obtained in England." 11

At the end of the century the Japanese government decided to dispense with foreign advice, and gradually the government and private railways would be built and managed without any assistance from foreigners in Japan, the materials alone being purchased abroad. In this change of circumstances, Great Britain was less competitive than their American competitors, the reason being that, in Britain, advisers, designers, and manufacturers were each independent, belonging to different firms, and manufacturers had nothing to do with the preparation of designs. The lack of consolidation of manufacturers with marketing in Britain was inferior to American competitors.

On the other hand, American manufacturers employed advisers and designers, so they could deal promptly with orders and attend to customers' requirements. This was one reason why British business began losing competitiveness in Japan. ${ }^{15}$

When Edmund Morell came to construct the first railway (the Tokyo-Yokohama line), Masaru Inoue participated in the construction. Born in 1843, he violated the law of the Edo government, which

${ }^{13}$ Nihon Kōtsū Kyōkai, ed., Tetsudō serijinıroku [Biographies of railway pioneers in Japan] (Nihon Teishajō Kabushikigaisha, 1972), pp. 392-95; Yoshihiko Morita, "Edmund Morel, a British Engineer in Japan," in Britain and Japan: Biographlical Portraits, ed. Ian Nish, vol. 2 (Japan Library, 1997), pp. 48ff.

14 “British Manufactures and Japanese Railway Development," The Times, 21 April 1896.

15. "British Manufactures and Japanese Railway Development," The Times, 21 April 1896. Japanese technology at the end of the nineteenth century was capable of manufacturing locomotives at a Kobe factory, and the performance of these locomotives was not inferior to that of locomotives imported from overseas. 
prohibited Japanese from going abroad, by going to England in 1864 with other colleagues of the same feudal clan; there he learned mining and railway technologies at the University College of London. Returning to Japan in 1868 , he joined the first national railway plan as an interpreter. He became the first head of the Railway Office when it was established in 1871, and he retired in 1893.

He was the doyen of the railway in the early Meiji period and contributed to the development of the Japanese railway industry for more than 20 years. His original belief was that the government should own and control all the railways, but, owing to the scarcity of public money, later on he had to make a concession and permit the existence of private railways. Inoue's convictions were an important factor behind nationalization. His two pet ideas were that the country's main railway should be under the control of the government, and that the gauge of the railway should be changed from 3 feet 6 inches to the standard gauge of 4 feet $8 \frac{1}{2}$ inches. The idea of government control was adopted by the majority of bureaucrats. The idea of changing the gauge was sidelined until the building of the Shinkansen after World War II; emphasized instead because of the limited resources for railway construction was the extension of the railway network. ${ }^{16}$

For ten years after the opening of the Tokyo-Yokohama Railway in 1872, the government lines were the only railways in the country, and these made very slow progress, for by 1882 only 122 miles had been constructed. At the time, people generally looked upon railways as a government preserve, and no attempt was made by private capital in other parts of the country to invest in this new form of enterprise.

The first grand project for a private railway was the construction of one from Tokyo to Aomori, the northernmost city on the main island of Honshū. In 1881 Tomomi Iwakura received permission to set up the first private railway in Japan; he conceived of the project as a means for investing the surplus funds of the country's nobility. Therefore

${ }^{16}$ Inoue Masaru, Shishąu Inoue Masaru-kun shōden. [A short biography of Viscount Inoue Masaru] (Tokyo, 1913), pp. 41-43; Yumiyo Yamamoto, "Inoue Masaru: 'Father' of the Japanese Railways," in Britain and Japan: Biographical Portraits, ed. Ian Nish, vol. 2 (Japan Library, 1997), pp. 21ff.

It would be an interesting topic to make clear the reason why Inoue was keen on nationalization while he spent time in England, where there were no railways run by private companies. Was he influenced by any local arguments for nationalization? 
its principal shareholders were members of the Imperial Household and various noble families. Though a private venture (called Japan Railway Company), it was in fact constructed under the supervision of government officials and subsidized by the government, which provided part of the dividend. The investment proved a profitable one, for although the company's railway does not by any means serve the most important commercial part of Japan, its profits were the largest of all the private companies.

The success of Japan Railway Co. caused a boom in railway promotions among businessmen and investors. Between 1885 and 1892 , 50 schemes were proposed, of which only 12 came to fruition. Under the pressure of establishing a modern transport system to serve industrial needs, private railways extended rapidly: the total mileage of private railways increased to 853 miles in 1890, and then to 1706 . miles in 1895; this far exceeded the mileage of the national railways, which stood at 553 miles in 1890 and 596 miles in $1895 .{ }^{17}$

The legislation enacted at various periods to aid the development of the railways began with the Private Railway Ordinance issued in 1887, a measure that was followed by a huge increase in the mileage of lines. In 1900 the Private Railway Law and Railway Operation Law were promulgated, completing the legislation desired by private companies. But follow-up measures were found to be needed as the years passed. Companies desiring to expand operations were hampered by a shortage of capital, which they could not obtain in any large amounts because of their inability to mortgage any of their property.

To remedy this the Government produced the Railway Mortgage Law, under which a private joint-stock railway company "may form a railway foundation with all or part of its railway lines, land for railway use or attached to the railway's rolling-stock, and instruments and appliances appertaining thereto, and make the aforesaid foundation the object of a mortgage" that must not exceed the amount of its paidup capital, less the amount of existing debentures. When this law came into force, a new era of railway expansion was predicted, and negotiations were entered into for capital from abroad. With talk of a railway nationalization scheme in government circles, private railway

${ }^{17}$ Takeshi Yuzawa, "The Transfer of Railway Technologies from Britain to Japan, with Special Reference to Locomotive Manufacture," pp. 205-206. 
Table 3. State Railways and Private Railways (Unit: Miles)

$\begin{array}{lcr}\text { Year } & \text { State railway } & \text { Private railways } \\ 1887 & 244 & 293 \\ 1888 & 445 & 406 \\ 1889 & 550 & 525 \\ 1890 & 550 & 848 \\ 1891 & 550 & 1,165 \\ 1892 & 557 & 1,320 \\ 1893 & 580 & 1,366 \\ 1894 & 580 & 1,537 \\ 1895 & 593 & 1,679 \\ 1896 & 631 & 1,800 \\ 1897 & 661 & 2,282 \\ 1898 & 768 & 2,642 \\ 1899 & 832 & 2,802 \\ 1900 & 949 & 2,905 \\ 1901 & 1,059 & 2.966 \\ 1902 & 1,226 & 3,010 \\ 1903 & 1,344 & 3,140 \\ 1904 & 1,461 & 3,228 \\ 1905 & 1,531 & 3,147 \\ 1906 & 3,116 & 1,691 \\ 1907 & 4,452 & 445 \\ & \text { Years of Japanese National Railways, vol. } & 4 . \\ & & \\ & & \end{array}$

companies showed no further desire to make loans and awaited the result of the government's nationalization act. ${ }^{18}$

MOVES FOR NATIONALIZATION OF JAPANESE RAILWAYS

Moves to nationalize the railways were started three times around the turn of the century: first in 1890 in the economic crisis that followed the first railway boom; then between 1897-98 and 1901, at the time

${ }^{18}$ Tetsudō jîhō [Railway times], 7 July 1909. 
of the economic depressions that followed the second railway boom; and finally during the Russo-Japanese War. This third push for nationalization was more successful, and it led to action being taken in 1906.

The first push for nationalization was made during the depression that followed the first railway boom and at a time when the prices of railway shares dropped heavily in 1890. Masaru Inoue proposed nationalization of the railways, and in 1891 he put forward to Prime Minister Hirobumi Itō a railway policy proposal entitled "Tetsudō seiryaku ni kansuru gi" (A proposal for a railway plan), in which he suggested the government assume construction of the main railway for the benefit of all sectors of Japan because the railway could be used for strengthening the country's military and economic power. Inoue offered ideas on how to raise money for the construction of that railway and for buying up the private railway companies. The Itō cabinet proposed bills for the issuance of railway bonds, the purchase of the main private railways, and a railway construction plan. The first two bills were defeated, but the third was enacted in 1892 as the Railway Construction Law, which outlined the government's policy for a national railway network. This was the first grand design of a railway policy made public by a Meiji government.

The reason why the bill for purchasing the private railways was lost at this time was that the shareholders of the major railway companies strongly opposed this proposal, even though they considered it a useful tool for keeping share prices at certain levels. The Mitsui and Mitsubishi zaibatsus were especially strong in asserting that, instead, the state-owned railway should be privatized, because they felt the British style of railway ownership was ideal. Ukichi Taguchi was an influential spokesman for this position.

After the Sino-Japanese War (1894-1895) was over, a second railway boom occurred, and the rush to construct railway lines was participated in not only by the private railway companies but also by the state railway. Severe competition between the private and state railways followed. Soon after the railway boom subsided, however, the shareholders of mostly small and local railways, who were suffering severely from the depression between 1897 and 1898, asked the government to purchase their railways. Though the push for nationalization came mostly from such shareholders, their cause was supported 
by local chambers of commerce in places like Osaka, Kobe, Kyoto, and Tokyo. This time, also, the small railway companies were unable to manage their lines well, and they wanted public financial support. They were all opposed, however, by leading capitalists such as the major zaibatsu enterprises, which were not keen on nationalization.

After the Russo-Japanese War (1904-1905) there was another push for nationalization, and a bill was prepared by the Katsura Cabinet (and supported by the Saionji Cabinet that followed it) in 1905. The Imperial Diet discussed from 6 March 1906 how to purchase the railways, how to estimate costs, and when steps should be taken. This time in the business world it was not only the shareholders of railways that were in favor of nationalization but also most zaibatsu enterprises. (Takaaki Katō, foreign minister in the Saionji Cabinet and son-in-law of Yatarō Iwasaki, representative of the Mitsubishi zaibatsu, opposed the bill and resigned his post when it passed.) Even Eiichi Shibusawa, the doyen of the business world, expressed acceptance of nationalization, though he opposed it previously.

\section{THE PROS AND CONS}

Theoretically speaking, a railway network under state control is preferable to that under different private companies that make plans for investment that are based upon their own ideas, which sometimes include the idea of competing with other companies, and there is a lot of scope for duplication of resources. To make full use of the resources of a nation, a state railway seems to be ideal because it can allocate and distribute the resources reasonably and effectively.

In addition, a financial reason was persuasive to the government, because all the loans would be completely paid off within 35 years by the working surplus, and an addition of 50 million yen would be made to the national treasury. ${ }^{19}$ The railway surplus dreamt of by the administration would be very helpful in any reorganization of finances.

Pratt explained the Japanese railway nationalization as follows: "It was affirmed that the Japanese Government aimed at strategical rather than at economical advantages, and that the military power

${ }^{19}$ E. Pratt, The Case against Railway Nationalisation, p. 59. 
of the country was mainly responsible for the project." ${ }^{20}$ In fact, military reasons would have been cogent, and consolidation of the railway network looked essential after the experience of the RussoJapanese War.

Watarai put a question about the necessity of military transport at a time of war: "It is to be questioned whether, during the war with Russia, the railways were really so deficient that their nationalization was absolutely necessary...despite the reply of the Minister of War to Oishi's question on this matter in the meeting of the committee of the Lower House, I do not believe that the private railways were so very defective for military ends." Watarai stresses that "the spirit of enterprise that existed to some extent before the war always needed the support of the state, and was accustomed to profit by relations with the government." ${ }^{21}$

Needless to say, military authorities were also in favor of nationalization, but their support was something akin to the way the Treasury supports any plan that raises revenue rather than for any other reason. Eiichi Shibusawa, the famous Meiji businessman, also had reservations about nationalization at first, and changed his opinion later. ${ }^{22}$

Tokugorō Nakahashi, president of Osaka Merchant Shipping Company, asserted that a railway was, by nature, a monopolistic enterprise, and private railway companies were now building up so much power that they were oppressing the rest of society. It was quite difficult to regulate railway companies by acts and orders, and nationalization of the railway was therefore essential. ${ }^{23}$

Köi Furuichi, doctor of engineering, chairman of the Seoul-Pusan Railway in Korea, stressed the monopolistic character of railways, and therefore the need for them to be state-owned. He supported the

${ }^{20}$ Ibid., p. 39.

${ }^{21}$ Toshiharu Watarai, Nationalization of Railunays in Japan (AMS Press, 1968 [1915]). I agree with his argument because, as far as I have been able to check in the Telsudo jih. (The Railway Times), I could not find serious articles complaining about the deficit of transportation during the Russo-Japanese War.

${ }^{22}$ Tatsujirō Ishikawa and Mitsuhide Imashiro, The Privatization of Japanese National Railuclys, p.10.

23. Tetsudō jihho, 24 February 1906. Nakahashi later became director of the Railway Bureau, a minister of education, and a minister of commerce and industry. 
view that the change of the existing gauge to a standard gauge was less urgent than the extension or duplication of lines. ${ }^{24}$

Kenjirō Den was a supporter of nationalization. He had been a president of Kansei Railway and became a Member of Parliament in the House of Lords, after some time as vice minister of the Department of Communications. He denied the possibility that prices of the national bonds for railway nationalization would fall, even if the bond issue would be quite large, because of articles in the Railway Nationalization Law that regulated any sudden drop in bond prices in the market by controlling the issue of additional bonds. ${ }^{25}$

Kakugorō Inoue, director of Hokkaido Tankō [Mine] Railway, warmly supported railway nationalization from early on, because he felt consolidated management under state control would produce greater efficiency in running trains and a reasonable fare system nationwide. He did not, however, accept the idea of using a national railway as a source of money for the central government. He supported nationalization on the grounds of consolidated management, not as a means of producing profit for the national treasury. ${ }^{26}$

Isoo Abe, a socialist, naturally was for nationalization of the railway, because the railway was a public transport, and it should not be left in the hands of capitalists. Railways should be constructed even in sparsely populated areas, and they should be used by common people, like roads, for cheap fare and rates. ${ }^{27}$

During the debate in the Diet the government pointed out four reasons for nationalization. The first was a military one, especially in a time of emergency when the rapid deployment of troops and war supplies was urgent. The second was that nationalization would lead to reasonable and effective management of through-traffic on a national scale; rolling stock, stations, and other facilities would be used economically and a reasonable fare system would be introduced-a system of decreasing the price in proportion to distance would be one possibility - and the number of managers and organizations would be reduced after consolidation of the companies. The third was that

\footnotetext{
${ }^{24}$ Ibid.

25. Idem, 17 February 1906.

${ }^{26}$ Idem, 17 February 1906.

27 Idem, 3 March 1906.
} 
a financial purpose would be served by nationalization, because in the near future the state-owned railway could yield a profit by reducing the number of managers and consolidating facilities, as happened in Germany, where 20,000 marks was paid into the national budget twenty years after nationalization of the railway. The fourth reason was that nationalization would provide cheaper fare and rates for traders and consumers, and this would encourage economic growth. ${ }^{28}$

Several journals opposed railway nationalization. Tökyō keizai zasshi [Tokyo economic journal] represented the opinions of industrialists and merchants (though there was some shift in opinion after the depression of 1890). Ukichi Taguchi, one editor of the journal, was strongly influenced by Adam Smith's ideas, and he was one of the pioneer advocates of free competition and free trade in Japan at that time. He maintained that railway nationalization would necessarily lead to a monopoly and might decrease the competition among the railways.

Taguchi died in 1905, and Kōtarō Noritake, his successor, also opposed nationalization. He contended that if the main railways came under the control of the state, competition would disappear among the railways, and that the timing of nationalization was not proper given the tight fiscal situation existing after the Russo-Japanese War. As for deployment of military forces and goods during that war, private railways coordinated with each other well and he had seen no serious problems in their deployment. He especially railed against nationalization as a kind of socialistic policy, and he doubted the government could manage a nationwide organization better than the way they were run by the private companies. He forecast that a nationalized railway would take in less revenue than was taken in before nationalization..$^{29}$

The press, for example the Asahi, Mainichi, Jiji, and Yorozu newspapers, was taking a liberalist stand, and they "generally considered nationalization to be nothing less than suppression of the spirit of individual enterprise by the power of the state, and an act prejudicial to

${ }^{28}$ Idem, 12 February 1906.

29. Yoshinobu Oikawa, "Sangyō kakumei-ki no tetsudō mondai to Tökyō keizai zasshi [Railway problems and Tokyo Economic Journal during the Industrial Revolution], in Tagucchi Ukichi to Tōkyō keizai zasshi [Ukichi Taguchi and Tokyo Ecomomic Journıl], ed. Shirō Sugihara and Kazunobu Okada (Nihon Keizai Hyōronsha, 1995), pp. 237-69. 
Takuzō Ushiba, president of San'yō Railway Company and one of the few who was exceptionally opposed to nationalization at this time, offered to restrict the profits and dividends of his company, and if the profits and dividends were over a certain limit, the surplus would be given to the government. If companies disliked offering surpluses to the government, they would reduce fares and rates, or increase investment to extend lines and secure greater safety. ${ }^{31} \mathrm{He}$ insisted that his idea was much better than nationalization.

Naoharu Kataoka, president of Kansei Railway, later president of Sangū Railway, also criticized nationalization from the perspective of railway interests, saying that the government should observe a period of business rights; say 25 years, guaranteed to the companies by the Act; that the improvement of harbors and extension of lines were more urgent than nationalization; and that the calculation of costs of purchase was unreasonable and unfair, disregarding as it did the peculiarities of each company in terms of revenue and profit. ${ }^{32}$

\section{THE PROCESS OF JAPANESE RAILWAY NATIONALIZATION ${ }^{33}$}

Purchase prices were decided by the formula: cost of construction $\mathrm{x}$ average rate of profit for three years preceding nationalization $\mathrm{x} 20$; for railway companies that had been operating for less than three years, the price was negotiated within the range of the real construction cost. The total price to be paid out by the Treasury was 248,013,821 yen. According to the Law, this money was paid in the form of government bonds bearing 5 percent interest, and the bonds were handed over within 5 years counted from the date of purchase.

Most of the private railway companies accepted nationalization after the bill was passed in the Diet. Japan Railway Co., the largest of the private railways, had been established with the support of the government,

${ }^{30}$ Watarai, Nationalization of Railtuays in. Japann, p. 61; Tetsudō jih̀ō, 17 March 1906. Among the newspapers, support for nationalization came from the Kokumin, Yomiuri, Chügrai shōgyō, and Jinmin dempō newspapers.

31 Telsudo jihō, 1 January 1909 to 10 February 1909.

32 Idem, 17 and 24 March 1906.

${ }^{33}$ Tadashi Uda, "Tetsudō kokuyūka" [Railway nationalization], in Nihon no kigyō to kokka [Business and state in Japan], ed. H. Morikawa (Nihon Keizai Shinbunsha, 1976). A recent magnificent work is Steven J. Ericson's The Sound of the Whistle: Railroads and the State in Meiji Japan. (Council on East Asian Studies, Harvard University, 1996). 
the bill was passed in the Diet. Japan Railway Co., the largest of the private railways, had been established with the support of the government, and so it naturally accepted nationalization; Kōbu Railway (now the Chūō Line running east to west across Tokyo) easily acceded to nationalization because it was already connected with the existing state railways. Some of the private railway companies, however, resisted nationalization. Kansei Railway, paralleling the state railway, could compete with it in fares and services, and Kyushu Railway could manage its finances successfully because it was controlled by the Mitsubishi zaibatsu and was freighting coal in northern Kyūshū.

Table 4 shows the price list of nationalization. It will be observed that nine of the lines in the above table, namely Gan'etsu, Nishinari, Hokkaidō, Kyoto, Hankaku, Hokuetsu, Bōsō, Nanao, and Tokushima, were purchased at figures approximately equivalent to the sums actually spent upon their construction, whereas eight companies were assessed at figures greater than actual outlays, some more than twice greater. The explanation is that the nine companies paid approximately their construction cost had been working at a loss and it was therefore impossible to apply to them the normal formula of estimating the price at twenty times the net profit. The Law provided that nonprofitable lines were to be purchased at actual cost. Of course, the Law did not invest the government with arbitrary power to acquire such railways at their cost price. If their owners were dissatisfied, they were entitled to appeal to the Minister of Communications, who was authorized to appoint a committee of assessment.

More than half of the lines were bought up within a few months of the passing of the Law; consequently, the discretionary power created by an amendment of the House of Peers, which authorized the government to extend the transaction over a period of 10 years, was virtually a dead letter. The total amount of bond issued was $456,195,000$ yen, and the financial market for Japanese securities was the source of some anxiety. ${ }^{34}$

The financial compensation paid to the private shareholders was equal to approximately double the paid capital. This means the purchase price was slanted in favor of the shareholders. From the point of view of the national economy, nationalization of the railways made

${ }^{34}$ Telsudō jihtō, 28 July 1906. 


\begin{tabular}{|c|c|c|c|c|c|}
\hline Company & date & mileage & constr'n cost & bond issue & paid capital \\
\hline Hokkaidō Tankō & 1906 & 207 & 11,486 & 30,997 & 12,650 \\
\hline Köbu & 1906 & 28 & 3,819 & 14,600 & 2,665 \\
\hline Japan R'way & 1906 & 860 & 53,678 & 142,524 & 58,200 \\
\hline Gan'etsu & 1906 & 112 & 2,723 & 2,422 & 2,640 \\
\hline San'yō & 1906 & 433 & 36,263 & 76,639 & 36,100 \\
\hline Nishinari & 1906 & 4 & 1,753 & 1,847 & 1,650 \\
\hline Kyūshū & 1907 & 495 & 51,073 & 118,508 & 50,300 \\
\hline Hokkaidō & 1907 & 158 & 10,479 & 6,132 & 6,340 \\
\hline Kyoto & 1907 & 22 & 3,458 & 3,296 & 3,420 \\
\hline Hankaku & 1907 & 70 & 6,379 & 4,284 & 4,000 \\
\hline Hokuetsu & 1907 & 101 & 7,156 & 3,722 & 3,700 \\
\hline Sōbu & 1907 & 74 & 5,304 & 12,406 & 5,760 \\
\hline Bōsō & 1907 & 39 & 2,055 & 960 & 1,040 \\
\hline Nanao & 1907 & 34 & 1,523 & 994 & 1,100 \\
\hline Tokushima & 1907 & 21 & 1,297 & 697 & 750 \\
\hline Kansei & 1907 & 299 & 22,993 & 30,438 & 24,182 \\
\hline Sangū & 1907 & 38 & 1,861 & 5,729 & 3,099 \\
\hline \multicolumn{6}{|c|}{ Source: Noda et al., Nihon no tetsudō, pp. 118-19. } \\
\hline
\end{tabular}

it possible to divert assets into other heavy industries. About 450 million yen-equivalent to about two-thirds of Japan's industrial, mining, and transport assets in 1907-were paid in the form of national bonds to shareholders, who converted them into cash and invested the money in other key industries. ${ }^{35}$

\section{AFTER NATIONALIZATION}

In 1906, 17 private railway companies were nationalized as the Kokuyū Tetsudō, or Japanese National Railways (JNR). As the result of nationalization, the government controlled 4,844 kilometers of tracks,

${ }^{35}$ Masao Noda et al., eds., Nihon no tetsudō-seiritsu to tenkai [Japanese railways: Their establishment and development] (Nihon Keizai Hyōronsha, 1986), pp. 114-21, dictionary. 
including unopened lines; 1,118 locomotives, 3,067 passenger carriages, and 20,884 freight carriages; and 8,409 employees. The national railways' share of transport jumped dramatically, from the prenationalization level of $32 \%$ to $90.9 \%$ in term of lines in operation. In terms of passengers per kilometer and freight per kilometer, the national railways had $83.7 \%$ and $91.4 \%$ of the total, respectively, compared with $37.7 \%$ and $29.4 \%$ before nationalization. The national railways had gained a monopoly over land transport.

At the time of nationalization, 147 different types of locomotives came under government control, a mixture resulting from the different countries and different manufacturers that had earlier supplied the Japanese railway companies. Needless to say, each company had its own style, reflecting requirements in the home country. The National Railways needed to overcome various difficulties to manage and operate them under a single standard rule.

After nationalization, the Tetsudō Sagyōkyoku (Railway Bureau) was renamed Teikoku Tetsudōchō (Imperial Railway Bureau) in 1907 and placed under the direct control of the Cabinet, which again changed its name in 1908 to Tetsudō-in (Railway Ministry). It was made up of five control divisions: Hokkaidō, Tōbu, Chūbu, Seibu, and Kyūshū. These divisions had a certain autonomy.

The accounting system was also standardized in 1906 under the Imperial Railway Accounting Law, and from 1909 the account of the Imperial Railway was separated from the general national budget and acquired autonomy to make clear the account of the Imperial Räilway. The railway bureaucrats also intended to increase their profit in the government.

The problem was how to control and manage the huge organization effectively and reasonably. The first president of the Tetsudōchō was Shimpei Gotō, who had been president of the South Manchuria Railway for about three years. He created a Kokutetsu daikazokushugi (Japanese National Railways familyism), an ideology designed to unify a staff of about 90,000 workers into a kind of family, bringing together numerous employees who had belonged to various private railway companies. Gotō had already tried to establish a similar idea in the South Manchuria Railway, and he transferred it to the newly organized Japanese National Railways. He also made an effort to change the railways from narrow gauge to standard gauge in order 
to increase traffic capacity, but the popular opinion at that time was that constructing new lines and extending old ones was more urgent than changing the gauge..$^{36}$

\section{CONCLUSION}

As K. Brown points out, "The contrast between the interventionist Japanese and the laissez-faire British epitomised in the latter's staunch adherence to free trade, should not be overdrawn, however. British governments were generally more interventionist than might at first appear, although the effects of their actions upon the economy were not always positive. While in most cases coming too late to explain a slowing of growth rates which began in the 1890s, a number of measures subsequently acted as brakes on the economy. These included fixing railway freight charges at rates that were not economically viable." "'Cheap Government" and "lassez-faire" have been strong slogans of British industrial policy, but in fact as far as the railway policy is concerned, no British government intervened at various stages, whether it was successful or not.

The development of the railways in both countries was quite similar. Both countries were confronting the important issue of railway nationalization at the same time. Japan entered into nationalization in 1906, but Britain, where heated debates about the merits and demerits of nationalization prevented such a move, in 1921 succeeded in consolidating all its railways into four large companies, which was a stage just short of nationalization. ${ }^{38}$

I would like to summarize my arguments in two points that will serve to contrast railway nationalization in both countries.

First, the role of the railways in the two national economies was different. At the end of the nineteenth century Britain was already a mature economy and railway construction was almost completed. It

${ }^{36}$ Noda et al., Nihon no tetsudō, pp. 133-34.

${ }^{37}$ Kenneth D. Brown, Britain and Japan: A Comparative Economic and Social History since 1900 (Manchester University Press, 1998), p. 15.

${ }^{38}$ It is beyond the scope of this paper to analyze the 1921 Act more precisely in regard to the reason why British railways were not nationalized at that time. The author intends to undertake a comparison later between the management and organization of Japanese and British railways between the two world wars. 
had 22,634 miles of railways in 1904, while Japan had only 4,236 miles in 1903. In the U.K. there were severe disputes between railway companies and traders over fares and rates and service in general (such as punctuality and delivery). This is the background to nationalization of railways in Britain. In Japan, however, industrialization was being accelerated from zero, as it were, and more railway construction was needed to build a nationwide network. For military and industrial purposes the railways were taking on an important role, and they needed much more capital to extend and duplicate their lines.

Second, in Britain the push for railway nationalization was advocated by traders who were angry at the high fares and rates in a time of depression and, more importantly, by labor unions imbued with socialism. The government was not positively disposed towards nationalization, nor was the military. In Japan, on the contrary, some of the capitalists, people in government, and the military led the move for nationalization of the railways, while the labor unions' influence was minor. One of the characteristics of Japan's nationalization was the lead taken by the government under the Saionji Cabinet. Traders' complaints about railway fares and rates were not a major motive for nationalization, nor was there any socialist pressure. The compensation for shareholders was not necessarily unfavorable, and they could make profits by investing in other industries that Japan needed at that time. 